\title{
Did desmid assemblages in Dutch moorland pools recover from acidification in the past century?
}

\author{
Herman van Dam • Koos (J.) Meesters
}

Received: 31 May 2021/Revised: 23 August 2021/Accepted: 31 August 2021/Published online: 26 October 2021

(C) The Author(s) 2021

\begin{abstract}
In order to monitor recovery from acidification caused by acid atmospheric deposition, desmids and water chemistry were sampled in three Dutch moorland pools regularly from 1978 to 2014 . Reference desmid samples from the early twentieth century were retrieved from old collections. Changes of the desmid assemblages were assessed by analyses of traits, including indicator values for $\mathrm{pH}$ and total phosphate, conservation value, cell volume and surface/volume (s/v) ratio. Direct correspondence analysis (DCA) traced relations between desmids and environmental variables. Between 1916 and 2014, species composition altered due to changes in acidifying atmospheric deposition: The change was most pronounced in pools with relatively flat shores exposed to the atmosphere in extremely dry summers. After the dry summer of 1921, changes were slight, but
\end{abstract}

We dedicate this paper to our teacher, friend and internationally renowned desmid expert, Dr Peter F.M. Coesel, on the occasion of his 80th birthday.

Handling editor: Judit Padisák.

H. van Dam $(\square)$

Consultancy for Water and Nature, Spyridon Louisweg

141, 1034 WR Amsterdam, The Netherlands

e-mail: herman.vandam@waternatuur.nl

Koos (J.) Meesters

Elbert Mooylaan 43, 1241 BB Kortenhoef, The

Netherlands

e-mail: meesters.j@gmail.com after the dry summer of 1976, changes were dramatic, when the sulphur and nitrogen compounds stored in the water bottom oxidized and acidified the water. The conservation value declined sharply but increased again until the 1990s, partly due to the decrease in acidifying deposition. Although the acid atmospheric deposition continued to decline until the early 21th century, the conservation value declined again, as did the stability of the desmid assemblages. It is likely that internal eutrophication (nutrients), presence of toxic substances (such as hydrogen sulphide), the decline of aquatic macrophytes (substrate), shading by afforestation (light) and/or reduced supply of carbon dioxide (due to decreased local seepage) play a role. The chemical dynamics due to the large stock of sulphur and nitrogen compounds will hamper the development of rare desmids, bound to stable environmental conditions.

Keywords Shallow lakes - Monitoring - Acid atmospheric deposition - Wetland recovery . Conservation value $\cdot$ Surface/volume ratio $\cdot$ Stability

\section{Introduction}

Acid atmospheric deposition is a significant threat to poorly buffered surface waters. Massive mortalities of salmon in Norwegian rivers were reported in the first half of the twentieth century, but only as late as the 


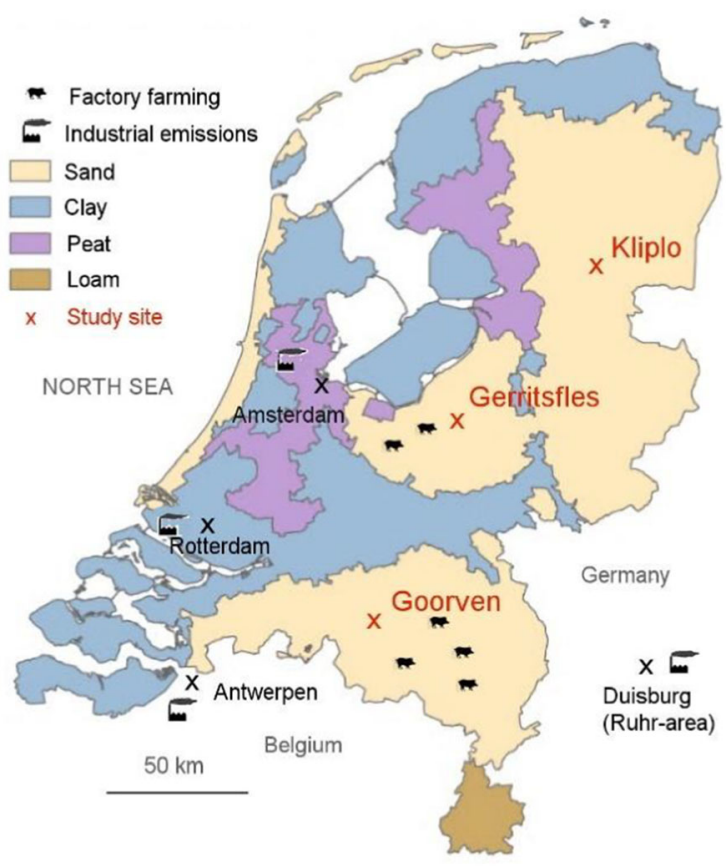

Fig. 1 Approximate location of sites in The Netherlands on a simplified soil map (www.rivm.nl)

early seventies, the fish dying was ascribed to acidification by atmospheric acid deposition, at that time mainly sulphur compounds (Jensen \& Snekvik, 1972). That year was the starting point for extensive research of the extent of acidification and its influence on aquatic ecosystems in Northern and Central Europe, showing that in non-buffered or weakly buffered waters, the structure (algae, macrophytes, invertebrates, fish, amphibians, birds) and function at all levels (production, decomposition) is affected by acidification (Hildrew, 2018). Since then, in the context of international programmes, many measures have been taken to reduce acidifying atmospheric deposition, which have been very successful for sulphur. For nitrogen compounds, such as ammonium, the deposition decreased too, but to a lesser extent than for sulphur (CBS et al., 2019).

The Netherlands, together with the surrounding regions of Belgium and Germany, are in the centre of the western European acidification area (Hettelingh et al., 2017). The acid-sensitive stagnant waters in this region are chiefly moorland pools. These shallow lakes, usually 1-2 m deep, have seasonally fluctuating water levels and are mainly fed by rainwater. The subsoil is sandy, poor in lime. Sometimes, the pools are partially filled with peat. They correspond to several protected European habitat types (oligotrophic waters containing very few minerals of sandy plains [Littorelletalia uniflorae]; natural dystrophic lakes and ponds; depressions on peat substrates of the Rhynchosporion). Moorland pools are the habitat for many rare plant and animal species, including Red List species, and are very vulnerable to anthropogenic disturbances such as acidification, eutrophication, and desiccation (European Commission, 2013).

Coesel et al. (1978) reinvestigated the desmids of moorland pools near Oisterwijk, in the south of the Netherlands. He found a considerable decline of diversity since the inventories by Heimans (1925) and was the first to demonstrate the impact of acidification on surface waters in the country. Since then, many publications have shown the disastrous influence of acidification on the biota in Dutch moorland pools, for example diatoms, macrophytes, macro-invertebrates, amphibians and fish (see review in van Dam \& Buskens, 1993).

Much research was done since 1975 on the influence of acidification reduction and restoration measures on biota, mainly macrophytes. Although the chemical monitoring indicates an apparent reduction in the acidification of pools (van Kleef et al., 2010), macrophyte communities do not automatically recover from acidification, mainly due to changes in the sediment composition. Recovery of macrophyte assemblages requires additional measures, such as dredging and supply of buffered ground- or surfacewater (Roelofs et al., 2002).

Single-celled algae, such as diatoms (Bacillariophyta), which are much less dependent on the structure of the sediment, do indicate a (partial) recovery of Dutch moorland pools from acidification (van Dam, 1996; van Dam \& Mertens, 2013). Therefore, it can be expected that also desmids will respond to the reduced acidification of the pools. In addition to the diatoms, these are the most common algae in moorland pools. Because we have not been able to find any examples of research into the recovery of desmid communities from acidification in the literature, we report here the results of a long-term study.

Initially, our project focussed on monitoring the recovery of desmid assemblages from acidification by atmospheric deposition of sulphur compounds and after a few years also from atmospherically derived nitrogen compounds. We expected an increase of the 
Table 1 Morphology of and acidifying deposition $\left(\mathrm{kmol} \mathrm{ha}^{-1} \mathrm{y}^{-1}\right)$ on moorland pools (van Dam, 1987; Arts et al., 2002); critical loads according to van Dobben et al., 2012)

\begin{tabular}{|c|c|c|c|c|c|c|c|c|c|c|}
\hline \multirow[t]{2}{*}{ Pool } & \multirow{2}{*}{$\begin{array}{l}\text { Area } \\
\text { (ha) }\end{array}$} & \multirow{2}{*}{$\begin{array}{l}\text { Maximal } \\
\text { Depth (m) }\end{array}$} & \multicolumn{4}{|c|}{ Sulphur deposition } & \multicolumn{4}{|c|}{ Nitrogen deposition } \\
\hline & & & 1997 & 2010 & 2020 & Critical & 1997 & 2010 & 2020 & Critical \\
\hline Goorven & 2.4 & 1.9 & 0.50 & 0.30 & 0.30 & 0.40 & 2.72 & 2.07 & 1.94 & $0.4-0.7$ \\
\hline Gerritsfles & 6.8 & 1.2 & 0.45 & 0.28 & 0.28 & 0.40 & 1.43 & 1.04 & 0.99 & $0.4-0.7$ \\
\hline Kliplo & 0.5 & 1.1 & 0.35 & 0.22 & 0.22 & 0.40 & 1.16 & 0.86 & 0.81 & $0.4-0.7$ \\
\hline
\end{tabular}

$\mathrm{pH}$ values, which were very low at that time, to values that would be more suitable for diverse desmid assemblages. However, due to the expected increase of biogeochemical processes (sulphate reduction, nitrification, etc.) in the pools, we did not expect that the composition of the desmid assemblages would return to the historical pre-acidification situation.

We test our expectations by describing changes in water chemistry, desmid traits (indicator values), surface-volume ratios, species composition and the relation between species composition and environmental variables.

\section{Materials and methods}

Locations

The Achterste Goorven, henceforth Goorven (near Oisterwijk, $51.5649^{\circ} \mathrm{N}, 5.2136^{\circ} \mathrm{E}$ ), is an elongated, medium-sized moorland pool (Table 1) and lies between mounds of aeolian drift sands, planted with
Scots pines in the nineteenth century. In 2004-2005, they were cut up to $30 \mathrm{~m}$ from the bank. The banks are relatively flat and largely dry in extremely dry summers (like 1976). The amplitude of the water level is about $0.8 \mathrm{~m}$. The pool is mainly rainwater fed, but groundwater drains a lot of ammonium and sulphate into the open water. The pool used to have a west-east gradient (in Fig. 2 from sample stations A to E) from higher to lower buffer capacity, nutrient concentrations and $\mathrm{pH}$, with plants from the Littorellion association and raised bogs. Today, there is a girdle of Myrica gale L. along the shore with Nymphaea alba L. and plants from acid pools, such as Juncus bulbosus L. and Sphagnum denticulatum Brid., regularly in the water. Station E was chosen for intensive sampling because it is the only one of the three stations where desmids were collected before and after the extreme drought of 1921. The deposition of sulphur and nitrogen compounds decreased significantly during the study period, but nitrogen is often higher than the critical load (Table 1). (a)

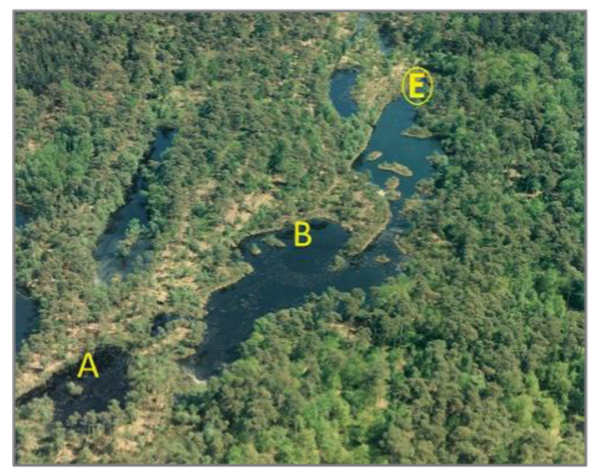

(b)

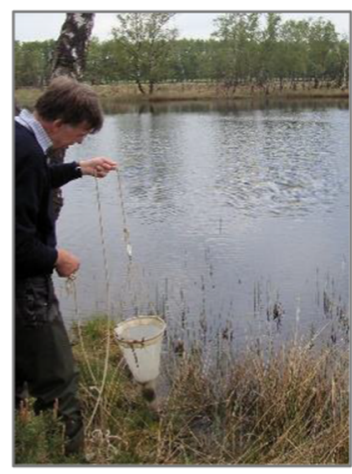

(c)

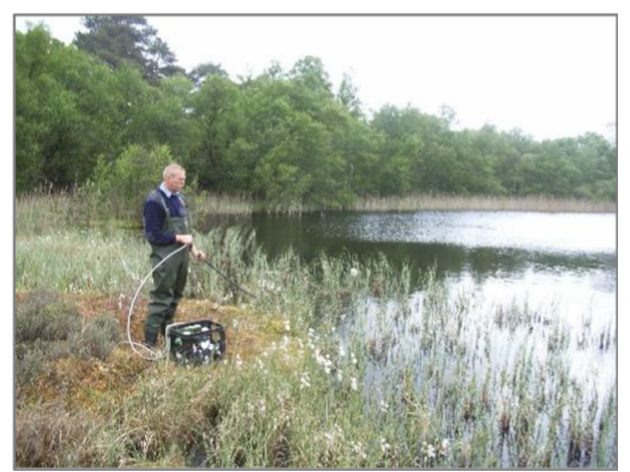

Fig. 2 a. Goorven in May 1992 with the permanent sample station (E) encircled (Photo: KLM Luchtfotografie). b. Towing Gerritsfles in May 2006 (Photo: Rita Hagen). C. Sampling chemistry in Kliplo in May 2006 (Photo: Herman van Dam) 
The Gerritsfles (near Kootwijk, 52.1598 $\mathrm{N}$, $5.8181^{\circ} \mathrm{E}$ ) was a small very wet heathland around 1800. Aeolian driftsand from the Harskamperzand caused the water level to rise and also supplied a lot of iron (oxide). As a result of reduction and oxidation processes, a high, upright and stagnant iron layer could form in the soil, above the groundwater. The pool has a perched water table. The amplitude of the water level is about $0.5 \mathrm{~m}$. In dry summers, a smaller part of the bank falls dry than in the previous moorland pool. Sheep washing in the nineteenth century stimulated the release of buffer substances, allowing Lobelia dortmanna L. to grow. Later, Scots pine trees grew along part of the bank. Until recently, the soil was covered with Sphagnum cuspidatum Hoffm., but this seems to be in decline. Along the banks, Juncus bulbosus flourishes, locally intermingled with Sparganium angustifolium Michx. During the study period, sulphur deposition dropped below the critical load, in contrast to nitrogen (Table 1).

Kliplo (near Dwingeloo, $52.8345^{\circ} \mathrm{N}, 6.4385^{\circ} \mathrm{E}$ ) is a small moorland pool, surrounded by birches, bare sand and a small quaking bog in a pine forest. It is situated higher than its surroundings due to an inverse in the relief and remains wet because rainwater stagnates on a poorly permeable layer. The banks are steeper than in the other two moorland pools, and in very dry summers, only a small part of the water body runs dry. The amplitude of the water level is about 0.4 $\mathrm{m}$. The moorland pool, which was once used as a duck decoy, has traditionally been very weakly buffered. Sparganium angustifolium, a Red List species, has been in decline for the last few decades. In the period 1989-1991 and from 2008 onwards, the water, which originally had a bright brown colour due to humic substances, was often clouded green by algae blooms. Potamogeton natans L. determines the aspect of the open water. The total deposition of sulphur was below the critical level in the study period, whilst nitrogen exceeded this level, but less than in the other moorland pools.

More details about history, geology and physiography are presented by van Dam (1987), van Dobben et al. (1992) and van Dam \& Buskens (1993).
Sampling and laboratory analysis

\section{Water chemistry}

From November 1978 onwards, samples were collected in February, May, August and September. Temperature, $\mathrm{pH}$ and conductivity were measured with Metrohm- or WTW-field equipment. Containers for laboratory samples were filled nearshore. The samples were kept at about their original temperature and transported to the laboratory, where they arrived within $48 \mathrm{~h}$ of sampling. Nutrients and macro-ions were analysed until 1995 by the laboratory of Waterleidingbedrijf Midden-Nederland using methods prescribed by the Netherlands Institute for Normalization (NEN) for examination of drinking water and from 1996 until 2014 in certified laboratories of regional water authorities, using NEN methods for the examination of surface water. Details are given by van Dam $\&$ Mertens (2019).

Great care has been taken to ensure comparability of the measurements over the whole period, e.g. by analysing samples both with old and new methods over a sufficient period of time. Generally, these methods were appropriate to determine the low concentrations in the pools, but particularly in the most recent samples, the values were frequently below the limits of reporting, e.g. $0.04 \mathrm{mg} / \mathrm{l} \mathrm{P}$ for total phosphate.

\section{Desmids}

From November 1978 onwards, samples were taken in May and November with a plankton net (mesh size $30-40 \mu \mathrm{m})$ that was pulled slightly through macrophytes (including Batrachospermum turfosum Bory, Nymphaea alba, Potamogeton natans, Sphagnum denticulatum, S. cuspidatum, Juncus bulbosus, Carex rostrata Stokes and Eleocharis palustris L.) if present and slightly through the upper sediment layer. The samples were preserved with formaldehyde (4\%).

In addition to these 'recent' samples, net plankton samples, taken by J. Heimans in the years 1916-1932 (now in Naturalis Biodiversity Centre, Leiden) were examined, supplemented with samples from later years from employees of the former Research Institute for Nature Management (now in Meise Botanic Garden). 
Slides were thoroughly searched for desmids at 100 to $120 \times$ magnification under bright field illumination with standard microscopes. Additionally, after 2006, an inverted microscope was often used because of the detritus in the samples. For measurements and difficult identifications, magnifications up to $630 \times$ were used.

For the identification, West \& West (1905-1912), West et al. (1923), Krieger (1937), Krieger \& Gerloff (1962-1969), Teiling (1967), Růžička (1977-1981), Förster (1982), Prescott et al. (1982) and Coesel (1982-1997) were used. For the samples after 2006, Lenzenweger (1996-2003) and Coesel \& Meesters (2007) were also consulted. Nomenclature follows Coesel \& Meesters (2007).

In the counts, no difference was made between vital and dead cells. Half cells, connected half cells (after division) and several connected cells (chains or fragments thereof) were considered one cell. Until 2006, a second slide was counted. If the differences between the two counts were small, this was sufficient. Usually, this was not the case, and the species composition differed in both counts. Then more slides were made and counted until no new species were recorded. For species-rich samples with much detritus, a maximum of six slides was examined. From 2006 onwards, usually four slides/cuvettes per sample were counted, but more if there was much detritus. The average number of cells per slide was calculated and converted to the abundance: 1 for $\leq 1$ (scarce), 2 for 1.1-100 (rather abundant) and 3 for $>100$ (very abundant). Thus, we followed a semi-quantitative assessment, as the actual abundances of taxa (which are almost impossible to be precisely estimated) are converted to class-level estimates.

\section{Data processing}

\section{Getting an overview}

In order to get an overview of the data of the 218 samples, the samples from 1978 onwards were grouped for each moorland pool into periods of seven to ten years. The older samples were divided into two to three periods per moorland pool. The boundaries between the periods were determined by constructing a matrix of the annual maximal abundances of all species found in each moorland pool. In the matrix, the samples were ordered chronologically for each pool. The species were ranked according to their abundance-weighted average year of occurrence. In this way, a diagonal structure per moorland pool was created in which apparent differences between the species composition of series of years became visible in drawing the boundaries. Account was also taken of the occurrence of extremely dry summers, such as those of 1921 (in August 1922, according to Heimans' notes, it was possible to walk right through the Goorven), 1947, 1959, 1976 (one of us walked right through this moorland pool) and 2003.

\section{Water chemistry}

For each moorland pool and each period, the average values of the quarterly data for physical and chemical data, including acid-neutralizing capacity (ANC), were calculated. Here, $\mathrm{ANC}=\mathrm{Ca}^{2+}+\mathrm{Mg}^{2+}$ $+\mathrm{Na}^{+}+\mathrm{K}^{+}-\mathrm{Cl}^{-}-\mathrm{SO}_{4}{ }^{2-}-\mathrm{NO}_{3}{ }^{-}$, in which the concentrations of the ions are expressed as $\mu$ eq/l (Reuss et al., 1986). Particularly, phosphate measurements are often uncertain because they are often close to, or even below, laboratory limits of reporting (0.02-0.04 $\mathrm{mg} / \mathrm{l}$ P-total).

\section{Desmid traits}

Coesel (1998) published a list of Dutch desmid species (infraspecific taxa are not distinguished) with the following indication values: $\mathrm{T}=$ trophic state with the categories 1 = oligotrophic, 2 = oligo-mesotrophic, 3 = mesotrophic, 4 = meso-eutrophic, $5=$ eutrophic, $\mathrm{i}=$ indifferent); $\mathrm{Z}=$ acidity with the categories $1=$ acidophilic,$\quad 2=$ acidophilic-circumneutral, 3 = circumneutral, 4 = circumneutral-alkaliphilic, $\mathrm{i}=$ indifferent; $\mathrm{H}=$ habitat ('life form') with the categories 1 = atmophytic - benthic, 2 = benthic, 3 = benthic - planktonic, $4=$ planktonic; $r=$ rarity with the categories $1=$ fairly rare, $2=$ rare, $3=$ very rare; $\mathrm{e}=$ ecosystem maturity (signal value) with the categories 1 = somewhat indicative, $2=$ moderately indicative, 3 = very indicative; RL = Red List with the category * (present).

For all our samples, these indicator values (traits) and then the conservation values were calculated according to Coesel's $(1998,2001)$ algorithm. The conservation values are based on the numbers of species, the rarity and the signal values of the species. For trophic state, abundance-weighted averages were calculated according to the formula $T=\sum a_{i} \bullet t_{i} / \sum a_{i}$, 
where $a_{i}$ represents the abundance and $t_{i}$ the trophic indicator number of the $i$-th species. Analogously, for acidity, $Z=\sum a_{i} \bullet z_{i} / \sum a_{i}$ is defined (i.e. not $\mathrm{pH}$ ), where $z_{i}$ stands for the acidity category number. Pals (2007) calculated the optimum values for $\mathrm{pH}$ and total phosphate (tP) of 52 desmid species from Flemish moorland pools. We used these values to infer abundance-weighted averages for $\mathrm{pH}$ and $\mathrm{tP}$ of our samples.

For each sample, the total number of species, the number of rare species and the percentages of species present in the habitat categories were calculated.

The frequency of each species is calculated for each site per period. This is the percentage of samples in which the species occurs. In addition, it is indicated whether the species occurs in one or more high abundance samples (class 3).

The stability is calculated as the average frequency per period of the species occurring in it. If all samples in a period are different, the stability is $0 \%$ and if they are identical, $100 \%$.

For each pool, the similarity with the samples from the oldest period was calculated using Sørensen's (1948) similarity index, which is equal to $2 w /(a+b)$, where $\mathrm{w}$ is the number of species occurring in both periods and $a$ and $b$ are the numbers of species from the first and second periods, respectively. With a value of 0 , there is no agreement between the periods; with a value of 1 , there is complete agreement.

Rank correlation coefficients according to Spearman were calculated between the mutual traits and between desmid traits and water chemistry.

\section{Dimensions}

Average cell volumes, cell surface areas and surfaceto-volume ratios ( $\mathrm{s} / \mathrm{v}$ ratios) were looked up in Bestová et al. (2018) and supplemented with observations from Neustupa et al. (2011). For eleven taxa not mentioned therein, calculations were made using literature estimates of the dimensions according to Coesel \& Meesters (2007).

As the mentioned parameters show a large spread and sometimes differ from each other by several orders of magnitude (from $83 \mu^{3}$ in Teilingia granulata to $1.38 \times 10^{6} \mu^{3}$ in Micrasterias rotata) and are skewed in their distribution, first the logarithms were taken, with which the abundanceweighted averages per sample were calculated (see also Bestová et al., 2018). These were transformed back to 'normal' numbers. In fact, geometric averages were calculated. From these geometric averages, arithmetic averages were calculated for each pool and for each period. From the period averages, Spearman rank correlation coefficients were calculated with the selected other traits.

\section{Ordination}

The traits are intended to convert the taxonomic composition of desmid assemblages found into a more or less easy to understand number. However, it is not possible to use them to investigate whether there might not be entirely new trends in the species and quantities found.

Therefore, the data were also processed with the ordination method DCA (detrended correspondence analysis), performed with Canoco version 5.04. We preferred DCA above PCA because of the long gradient (ter Braak \& Šmilauer, 2012).

For the years since 1979, usually two samples per pond are available. These have been combined to 112 annual samples by taking the maximum abundance of each species in the year concerning.

Of the 179 species, the 106 species found in five or more annual samples were selected for the calculations. The abundances have not been transformed when performing the ordination, but the rarer species have been given a lower weight.

After performing the ordination, Pearson correlation coefficients were calculated between the scores of the annual samples on the first four axes of the ordination and the environmental variables. These are annual averages of the quarterly values of chemical samples taken in the year of the desmid sampling. Except for $\mathrm{pH}$ and conductivity, all variables were first logarithmically transformed because of their skewed distribution. Most of the variables were measured at least from 1978 onwards. Systematic observations of total phosphate (tP) are available from 1991 and of total nitrogen (tN) only from 1997 onwards. $\mathrm{CO}_{2}$ was measured from 1981 to 1996 . Thus, some prudence is required in interpreting these three variables.

In addition to the environmental variables, the correlations of some desmid traits with the ordination axes were also calculated. These are the geometric averages of cell volumes and the s/v ratio per sample, the number of species, the number of Red List species, the percentage of atmophytic-benthic species, the calculated phosphate concentration and the calculated $\mathrm{pH}$. 
Table 2 Average values per period for selected physical and chemical variables in surface and rain water

\begin{tabular}{|c|c|c|c|c|c|c|c|c|c|c|c|c|c|c|}
\hline \multirow[t]{2}{*}{ Location } & \multirow[t]{2}{*}{ Period } & \multicolumn{10}{|c|}{ Surface water } & \multicolumn{3}{|c|}{ Wet deposition } \\
\hline & & $n$ & $\begin{array}{l}\text { Temp } \\
{ }^{\circ} \mathrm{C}\end{array}$ & $\begin{array}{l}\mathrm{pH} \\
-\end{array}$ & $\begin{array}{l}\mathrm{EC} 25 \\
\mathrm{mS} / \mathrm{m}\end{array}$ & $\begin{array}{l}\text { ANC } \\
\mu \mathrm{eq} / 1\end{array}$ & $\begin{array}{l}\mathrm{CO}_{2} \\
\mathrm{mg} / \mathrm{l}\end{array}$ & $\begin{array}{l}\mathrm{PO}_{4} \text {-tot } \\
\mathrm{mg} / \mathrm{l} \mathrm{P}\end{array}$ & $\begin{array}{l}\mathrm{SO}_{4} \\
\mathrm{mg} / 1\end{array}$ & $\begin{array}{l}\mathrm{NH}_{4} \\
\mathrm{mg} / \mathrm{l} \mathrm{N}\end{array}$ & $\begin{array}{l}\mathrm{Cl} \\
\mathrm{mg} / \mathrm{l}\end{array}$ & $\begin{array}{l}\mathrm{SO}_{4} \\
\mathrm{mg} / \mathrm{l}\end{array}$ & $\begin{array}{l}\mathrm{NH}_{4}+\mathrm{NO}_{3} \\
\mathrm{mg} / \mathrm{l} \mathrm{N}\end{array}$ & $\begin{array}{l}\mathrm{Cl} \\
\mathrm{mg} / \mathrm{l}\end{array}$ \\
\hline \multirow[t]{5}{*}{ Goorven } & $1925-1932$ & 2 & & 5.7 & & & & & & & & & & \\
\hline & 1978-1985 & 27 & 11.8 & 4.2 & 15.7 & -369 & 16.8 & & 29.8 & 2.4 & 15.2 & 9.2 & 3.1 & 3.8 \\
\hline & 1986-1994 & 36 & 12.8 & 4.7 & 12.2 & -233 & 10.2 & 0.016 & 22.8 & 3.1 & 13.5 & 6.1 & 2.5 & 3.4 \\
\hline & 1995-2004 & 42 & 12.9 & 5.2 & 7.9 & -73 & 7.7 & 0.051 & 11.0 & 1.8 & 12.2 & 3.7 & 2.2 & 2.6 \\
\hline & 2005-2014 & 38 & 12.0 & 5.4 & 5.2 & 24 & 3.5 & 0.048 & 6.6 & 0.8 & 7.0 & 1.9 & 1.6 & 2.0 \\
\hline \multirow[t]{5}{*}{ Gerritsfles } & $1925-1930$ & $10^{*}$ & 11.7 & 5.6 & 10.0 & & & & 18.0 & 0.1 & 15.3 & & & \\
\hline & 1977-1985 & 29 & 11.3 & 4.6 & 8.7 & -160 & 7.5 & & 14.6 & 1.3 & 9.4 & 7.4 & 2.6 & 4.6 \\
\hline & 1986-1994 & 36 & 12.8 & 4.3 & 6.8 & -94 & 4.8 & 0.019 & 9.3 & 1.1 & 8.3 & 5.3 & 2.2 & 4.6 \\
\hline & 1995-2004 & 36 & 12.3 & 5.1 & 5.3 & -75 & 2.9 & 0.032 & 6.9 & 0.7 & 6.8 & 3.3 & 1.8 & 3.6 \\
\hline & 2005-2014 & 35 & 12.2 & 5.1 & 4.2 & 2 & & 0.031 & 4.0 & 0.2 & 5.6 & 1.8 & 1.3 & 2.6 \\
\hline \multirow[t]{5}{*}{ Kliplo } & 1924-1929 & 3 & & 6.2 & & & & & & & & & & \\
\hline & 1978-1985 & 27 & 11.0 & 5.3 & 6.0 & -4 & 8.8 & & 5.4 & 0.5 & 11.6 & 5.4 & 2.1 & 3.2 \\
\hline & 1986-1997 & 48 & 12.2 & 5.2 & 6.9 & -42 & 5.7 & 0.032 & 7.6 & 1.3 & 12.0 & 3.5 & 1.8 & 3.0 \\
\hline & 1998-2004 & 28 & 12.6 & 5.2 & 4.8 & 23 & 2.5 & 0.046 & 4.0 & 0.2 & 7.9 & 2.1 & 1.4 & 2.5 \\
\hline & 2005-2014 & 40 & 12.0 & 6.5 & 3.8 & 49 & & 0.049 & 3.2 & 0.1 & 7.7 & 1.1 & 1.1 & 1.6 \\
\hline
\end{tabular}

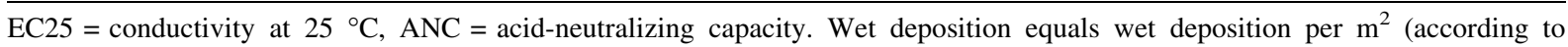
measurements of the national atmospheric network at RIVM), divided by the mean water depth. Values of incidental, colorimetric pH measurements and other historical measurements are printed in italics

*For pH only. for other variables $n=1$
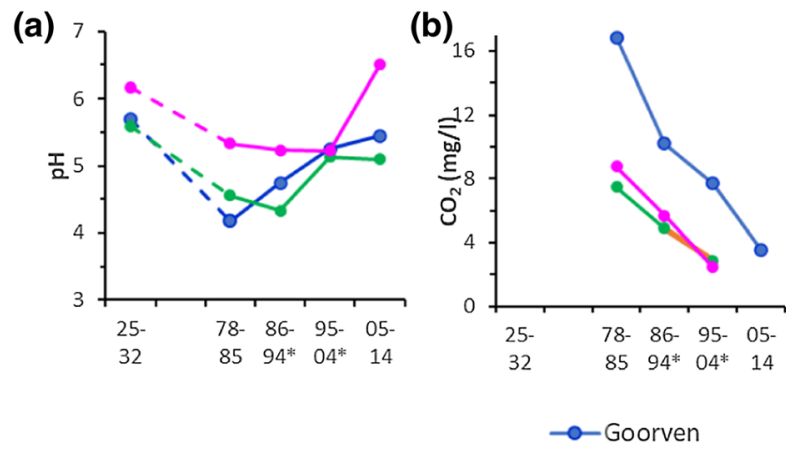

Fig. 3 Average values of selected chemical values in surface water between 1925 and 2014. Quarterly measurements between 1979 and 2014, incidental measurements in earlier

\section{Results}

\section{Water chemistry}

The individual chemical analyses are listed in Annex 4 of van Dam \& Mertens (2019). A summary is given in Table 2. The change of some variables relevant for the desmids is shown in Fig. 3. (c)

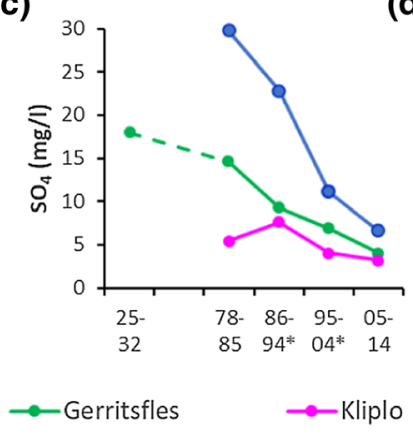

periods. *in Kliplo, the border between periods is not between 1994 and 1995, but between 1997 and 1998

The $\mathrm{pH}$ of the three moorland pools was around 6.0 in the 1920s. Between 1978 and 1994, it had dropped to averages just above 4 in Goorven and Gerritsfles, and to 5.3 in Kliplo. The lowest individual measurements in the first two moorland pools were 3.6 and 4.0, respectively. From the 1980s onwards, the pH rose again in Goorven and Kliplo to over 5.0 and in Kliplo to an average of 6.5 between 2005 and 2014. On nice 
summer days, values as high as 8.4 were measured here! Parallel to the increase in $\mathrm{pH}$, the carbon dioxide concentration decreases. In Goorven, this is much more than in the other two moorland pools. In the late 1970s, sulphate concentrations were high in Gerritsfles and Goorven. The relatively high sulphate concentration in Gerritsfles in 1930 is remarkable. The ammonium concentration was very low at that time and it peaked in 1983. In Kliplo and Goorven, ammonium levels peaked around 1991.

Parallel to the increasing $\mathrm{pH}$, the buffering capacity (ANC) also increases. This is not only due to the reduced concentrations of sulphate but also chloride. Phosphate concentrations seem to have been increasing since around 1990 (Table 2).

The water chemistry indicates that Goorven and Gerritsfles are recovering from the extreme acidification in the 1970s. Sulphate concentrations are now below the critical limit, but ammonium is still too high in Goorven. After the 1976 drought, carbon dioxide concentrations were high due to the decomposition of organic material.

\section{Desmids}

In Table 3, the mean values of selected desmid traits and some chemical variables are listed. Traits such as similarity, conservation value, number of species and number of Red List species are listed separately, although they are strongly correlated with each other ( $|r| \geq 0.75, p<0.001)$. The trophic index is highly positively correlated with the calculated phosphate concentration and the measured $\mathrm{pH}(\mathrm{r}>0.70$, $\mathrm{p}<0.005)$ and negatively with the percentage of atmophytic-benthic species $(r=-0.77, \mathrm{p}<0.005)$. The acidity index has only weak correlations with the calculated $\mathrm{pH}(r=-0.31)$ and the measured $\mathrm{pH}$ $(r=-0.28)$. The calculated $\mathrm{pH}$ and total phosphate concentration are correlated highly significantly $(r=0.84, \mathrm{p}<0.001)$. The calculated $\mathrm{pH}$ is not significantly correlated with the measured $\mathrm{pH}$ $(r=0.50)$. The calculated phosphate concentration is significantly $(\mathrm{p}<0.01)$ correlated with the measured phosphate concentration with $r=0.85$, despite the relatively high detection limits.

The similarity, the conservation value and the strongly correlated numbers of species and Red List species decrease sharply in the first half of the century and then more or less stabilize. In Kliplo, the changes were initially slower than in the other two pools, but eventually, this pond, too, declined. Especially between 1978 and 1985, the number of species in Goorven and Gerritsfles is extremely low at 8-9 (Fig. 4a). There is a small revival in the following period, but from 1995 onwards, there are only 11-15 species in both moorland pools. In Kliplo, the minimum (11) is between 1998 and 2004. After that there is an increase to an average of 19 species in the period 2005-2014, but this does not reach the 47 species between 1924 and 1929 .

In the pre-war samples, stability is high $(58-78 \%$, Fig. 4d). In the Goorven, stability is much lower than in the other two moorland pools (37-38\%) over the entire period 1978-2014 at 29\%. In the period 1978-1985 in particular, stability in Goorven is very low at $21 \%$. From 1986 onwards, stability decreased in Goorven and Gerritsfles. In Kliplo, stability drops to $30 \%$ in the period 1986-1997.

The low percentage of atmophytic-benthic species in Kliplo (Fig. 4e) is striking. This is probably due to the steeper banks, which, in contrast to the other two ponds, hardly dry out. The high percentages of atmophytic-benthic species in the middle periods in the other two moorland pools are related to the extremely dry summers of 1959 and 1976.

The changes in calculated phosphate concentration largely parallel those in calculated $\mathrm{pH}$ (Table 3, Fig. 4f). In Kliplo, the average $\mathrm{pH}$ in all periods is always around 5.1. In both other ponds, there is a substantial decline in the middle periods. The lowest average (4.2) is in the period 1978-1985 in Goorven. As shown in the previous section, this is a combined effect of high atmospheric deposition and the extreme drought of 1976. To a lesser extent, this is the case for the Gerritsfles. From about 1980 onwards, the moorland pools recover partially due to a series of less dry years and reduced atmospheric deposition of sulphur and nitrogen compounds (Table 1).

\section{Species composition}

Altogether 179 species were found, of which 137 in Achterste Goorven E, 103 in Gerritsfles and 143 in Kliplo. Exclusively in the 15 old samples (1916-1958), 25 species and exclusively in the 193 'recent' samples, 53 species were found, whilst 101 species have been seen in both periods. A selection of 54 species is listed in Table 4 (the table of all species is 


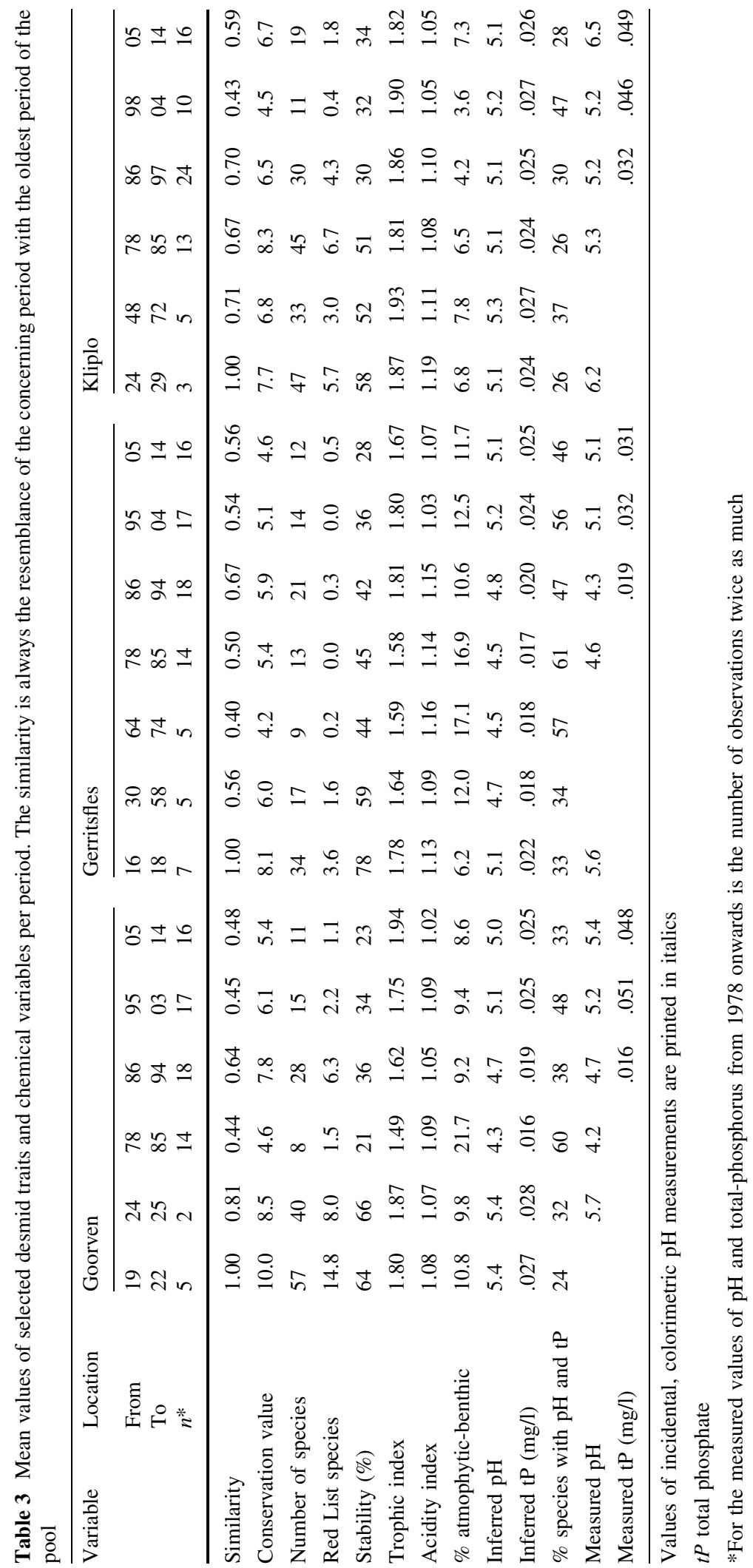



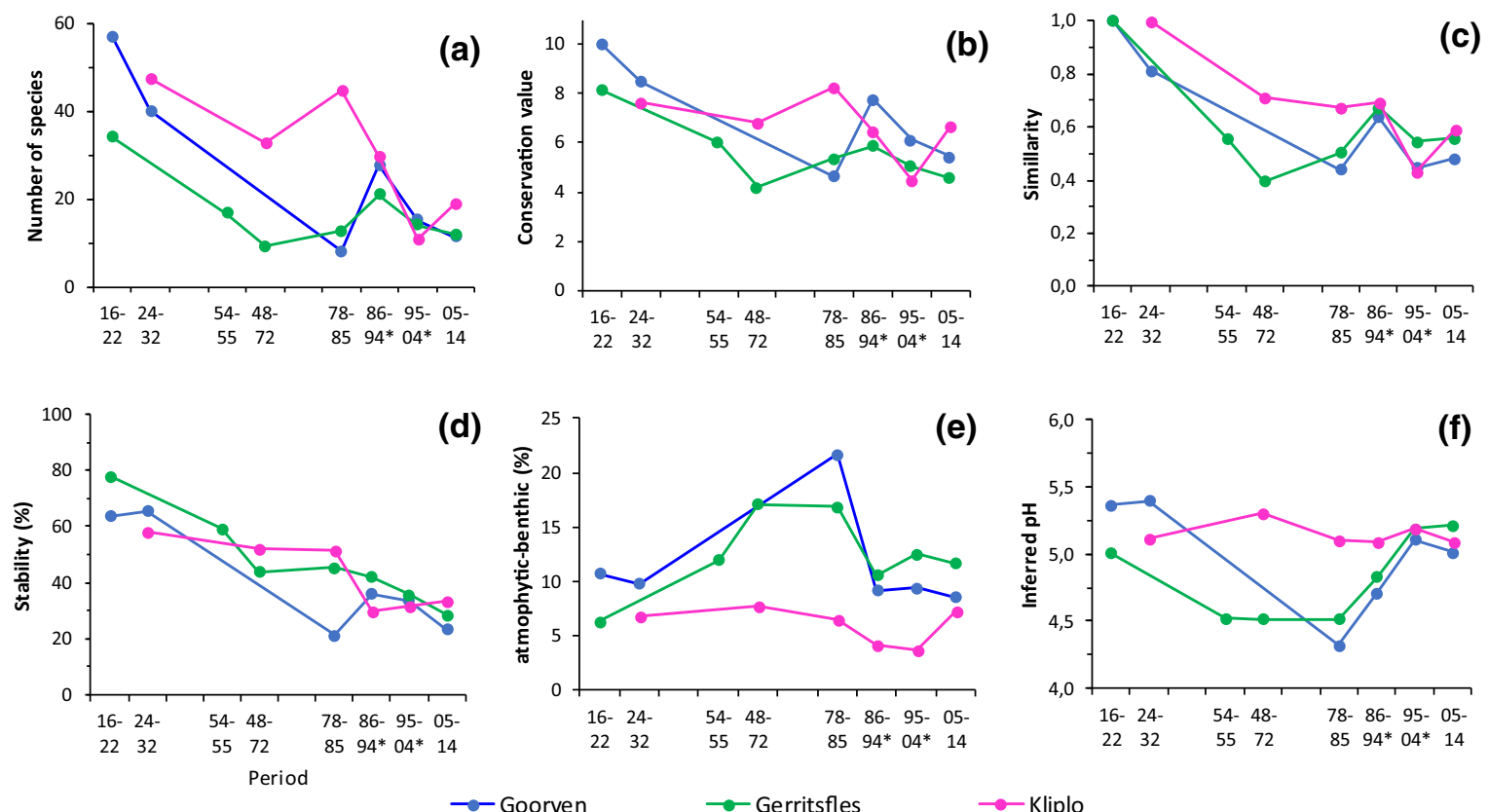

Fig. 4 Changes in mean values of desmid traits between 1916 and 2014. Semi-annual measurements 1979 and 2014 , incidental measurements in earlier periods. *in Kliplo, the period boundary is not between 1994 and 1995 but between 1997 and 1998

in van Dam et. al., 2021). The choice of the selected species is not entirely random. Some priority has been given to non-trivial species with known $\mathrm{pH}$ - and phosphate-optima. Mainly of the rare species, there are more data about the optima than of more trivial species. However, care has been taken to reflect the different distribution patterns in the different pools and periods in Table 4.

Closterium intermedium Ralfs, an acidobiontic species of oligo-mesotrophic waters, is most common. Bambusina borreri (Ralfs) Cleve, an acidophilic species of oligotrophic waters, also occurs at all three sites in all periods, regularly with larger numbers. Other species occurring in more than half of the 218 samples and almost all periods are common species of acidic moorland pools and bogs such as Actinotaenium cucurbita (Bréb.) Teiling, Staurodesmus omearae (W. Archer) Teiling, Cylindrocystis brebissonii De Bary, Micrasterias truncata Ralfs, Closterium abruptum W. West, C. directum W. Archer and Tetmemorus granulatus Ralfs. Micrasterias thomasiana W. Archer is a species of slightly mesotrophic waters and occurs, with increasing frequency, in the three moorland pools, especially in the samples after 1980.
The mesotraphentic Micrasterias rotata Ralfs develops mainly in Kliplo samples from 1978 to 2004 and occurs in Goorven and Gerritsfles only between 2005 and 2014: a clear sign of eutrophication. Some species have only been found in the most recent period, such as the extremely rare Euastrum crassicolle P. Lundell and E. luetkemuelleri F. Ducell in Kliplo.

Staurastrum punctulatum Ralfs is, next to Cylindrocystis brebissonii, one of the few species that occur en masse in the Goorven during the extreme acidification between 1978 and 1985. In that period, only 14 species occur in this moorland pool, with a low frequency.

\section{Surface and volume estimates}

The results are summarized in Fig. 5. The values of volume and surface area are highly significantly correlated $(r=0.98, \mathrm{p}<0.001)$ and increase with time $(r=0.58, \mathrm{p}<0.001)$. The area-volume ratios decrease in Kliplo from the period 1948-1972, in the Achterste Goorven from the period around 1990. There is no such decrease in the Gerritsfles. 
Table 4 Frequencies per period per site between 1916 and 2014 of selected species

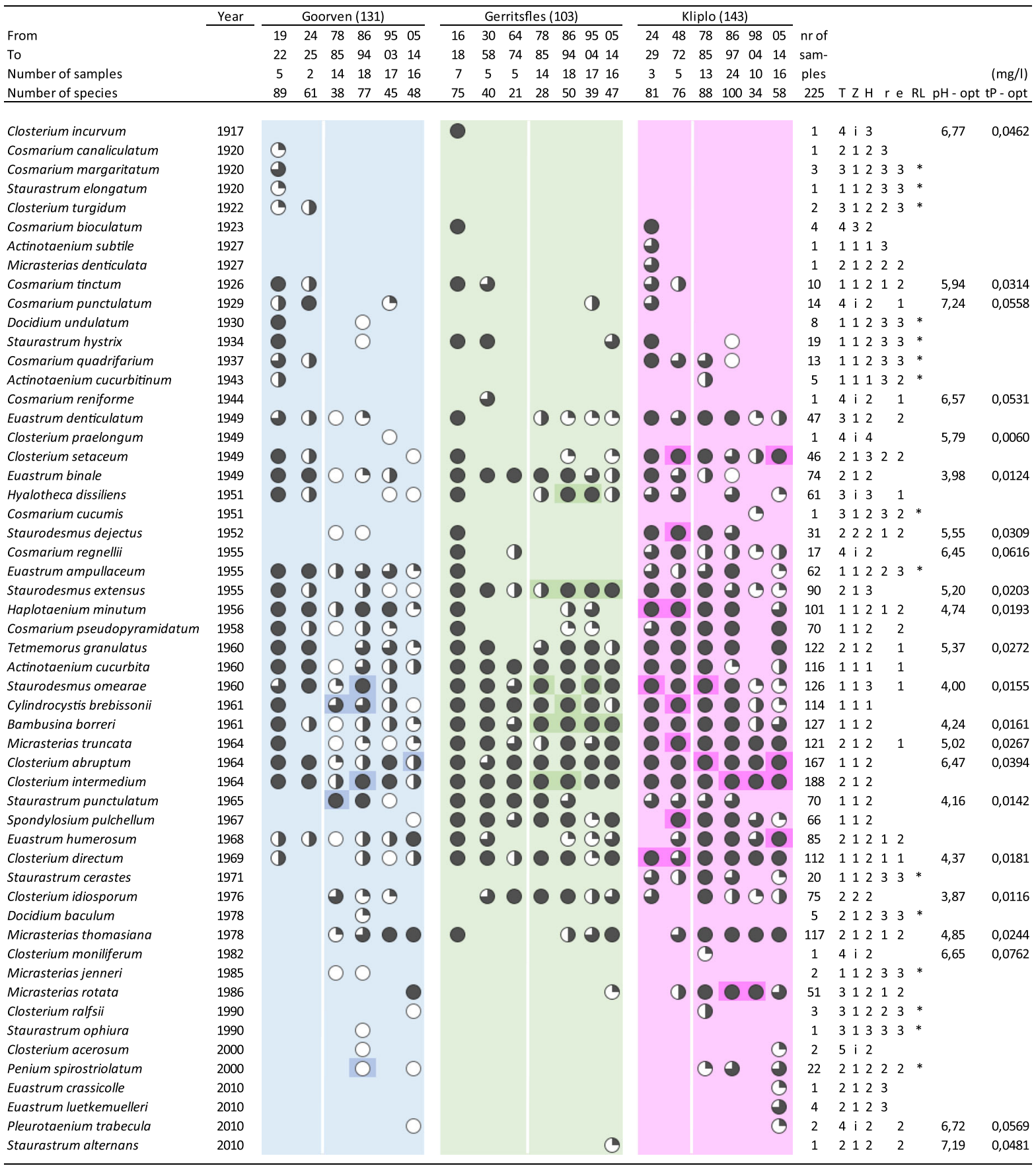

$1-20 \%,-70-40 \%,+70-60 \%, \bigcirc 60-80 \%, \bigcirc 80-100 \%$. 
Table 4 Continued

Species are ordered according to weighted average year of occurrence (Year). Symbols of species with high abundances (class 3) in one or more samples of a period are shown with a darker background. Behind the location names, the total numbers of species in the samples are given. T, Z, H, r, e and RL are indications for trophic state, acidity, habitat, rarity and ecosystem maturity, respectively, according to Coesel (1998), as explained in the text. Optima for $\mathrm{pH}$ and total phosphate according to Pals (2007)The vectors given in red were utilized for the calculation of the tilt angle as explained in the text.

(a)

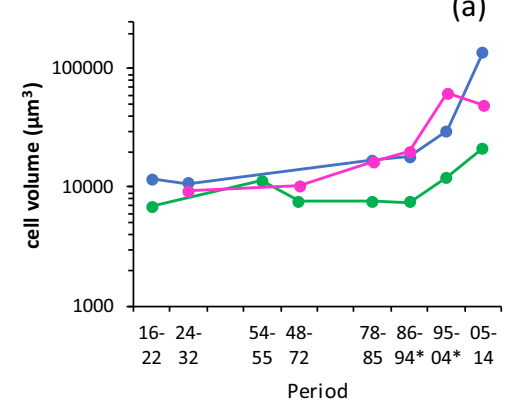

(b)

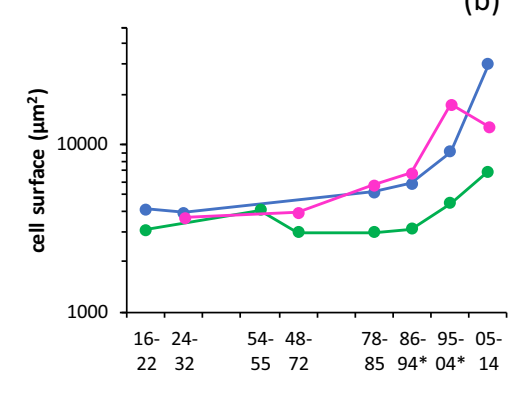

(c)

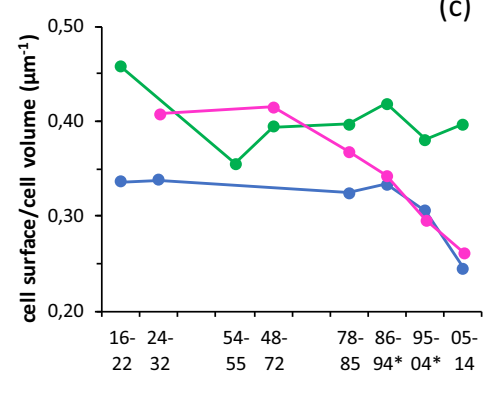

$\multimap-$ Goorven $\quad \longrightarrow$ Gerritsfles $\quad \longrightarrow$ Kliplo

Fig. 5 Changes in mean values of desmid dimensions between 1916 and 2014. Between 1978 and 2015, semi-annual measurements, before that incidental measurements. *in Kliplo, the period boundary is not between 1994 and 1995 but between 1997 and 1998

The average cell volume is lowest in the Gerritsfles with $7655 \mu^{3}$ and in both other moorland pools with $17503 \mu \mathrm{m}^{3}$ for Goorven and $18333 \mu \mathrm{m}^{3}$ for Kliplo it is about the same, but it seems that the increase in Achterste Goorven is faster. In the series Goorven,
Gerritsfles and Kliplo, the increase in one century is 12, 3 and 5 times the initial value, respectively.

The acidity indicator number is strongly negatively correlated with the cell content $(r=-0.79$, $\mathrm{p}<0.001$ ) and positively with the $\mathrm{s} / \mathrm{v}$ ratio

Fig. 6 a, c Evolution of the mean scores of the samples per period on the ordination axes. The periods are indicated with their average year. The explained percentages of variation are indicated near the axes. The lengths of the grey arrows are a measure of the correlation coefficients of the environmental variables from Table 4, those of the yellow arrows are a measure of the correlation coefficients of some desmid traits $(\mathrm{s} / \mathrm{v}=\mathrm{s} / \mathrm{v}$ ratio, vol = biovolume, $\mathrm{S}=$ number of species, RL = number of Red List species, \%a-b $=\%$ atmophyticbenthic species, $\mathrm{pH}-\mathrm{i}=$ inferred $\mathrm{pH}, \mathrm{tP}-\mathrm{i}=$ inferred total-phosphorus. $\mathbf{b}, \mathbf{d}$ Scores of the 60 most common species. Font size is a measure of cell volume. The colour indicates the trophic class according to Coesel (1998) (blue $=$ oligotraphentic, green $=$ oligomesotraphentic, orange $=$ mesotraphentic, red $=$ meso-eutraphentic, black $=$ indifferent for trophic state). Red List species are underlined. AcCuca = Actinotaenium cucurbita, BaBor $r=$ Bambusina borreri, $\mathrm{ClAbru}=$ Closterium abruptum, $\mathrm{ClAcut}=$ C. acutum, $\mathrm{ClBail}=C$. baillyanum, $\mathrm{ClCalo}=C$. calosporum, $\mathrm{ClClos}=C$. closterioides, $\mathrm{ClDire}=C$. directum, $\mathrm{ClGrac}=C$. gracile, ClIdio $=C$. idiosporum, ClInte $=C$. intermedium, ClJunc $=C$. juncidum, ClLunu $=C$. lunula, ClNavi $=C$. navicula, ClParv $=C$. parvulum, $\mathrm{ClSeta}=C$. setaceum, $\mathrm{ClVenu}=C$. venus, CoAmoe $=$ Cosmarium amoenum, CoAngu $=C$. angulosum, CoMarf $=C$. margaritiferum, CoOrna $=C$. ornatum, CoPspy $=C$. pseudopyramidatum, CoPyra $=C$. pyramidatum, CoSph $=C$. sphaeroideum, CoSutu $=C$. subtumidum, CoVari $=C$. variolatum, CyBreb $=$ Cylindrocystis brebissonii, EuAmpu = Euastrum ampullaceum, EuAnsa $=$ E. ansatum, EuBina $=$ E. binale, EuCras $=$ E. crassum, EuDent $=$ E. denticulatum, EuHume = E. humerosum, EuIner $=$ E. inerme, EuPect $=$ E. pectinatum, HaMinu $=$ Haplotaenium minutum, HaRect $=H$. rectum, HyDiss $=$ Hyalotheca dissiliens, MiRota $=$ Micrasterias rotata,$\quad$ MiThom $=M$. thomasiana, MiTrun $=$ Micrasterias truncata, NeDigi $=$ Netrium digitus, PlEhre = Pleurotaenium ehrenbergii, $\quad$ SdDeje $=$ Staurodesmus dejectus, $\quad$ SdExte $=S . \quad$ extensus, SdOmea $=$ S. omearae , SpPulc $=$ Spondylosium pulchellum, StBrac $=$ Staurastrum brachiatum, StGrac $=$ S. gracile, StHirs $=S$. hirsutum, StPara $=$ S. paradoxum, $\mathrm{StPoly}=S$. polymorphum, $\mathrm{StPunc}=S$. punctulatum, StTeli $=S$. teliferum, $\mathrm{TmBreb}=$ Tetmemorus brebissonii, TmGran $=T$. granulatus, TmLaev $=T$. laevis, XaAnti $=$ Xanthidium antilopaeum, XaArma $=$ X. armatum, XaOcto $=$ X. octocorne 


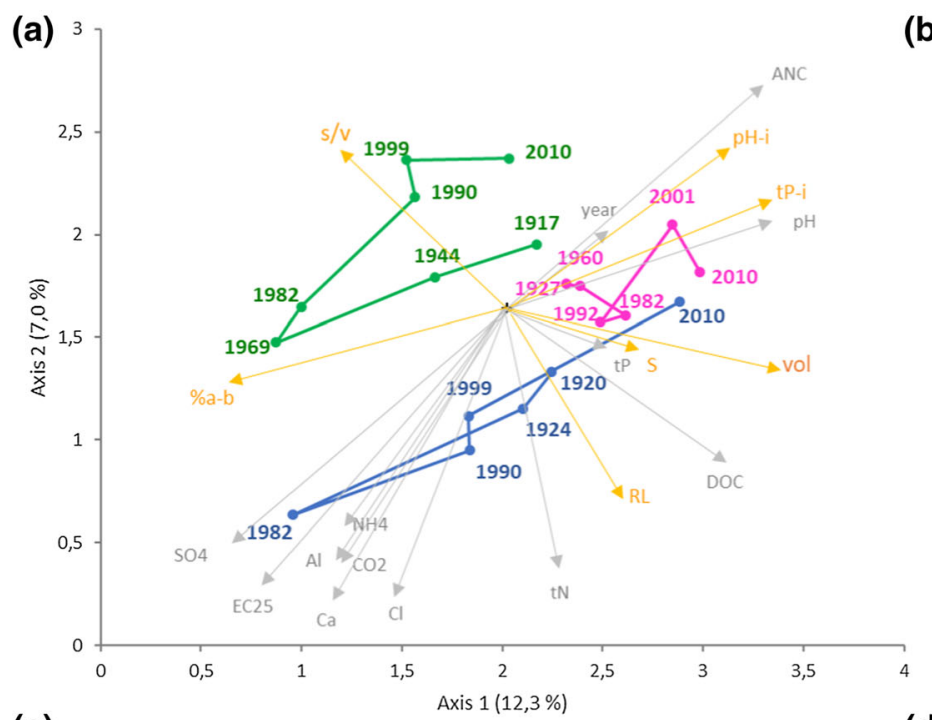

(c)

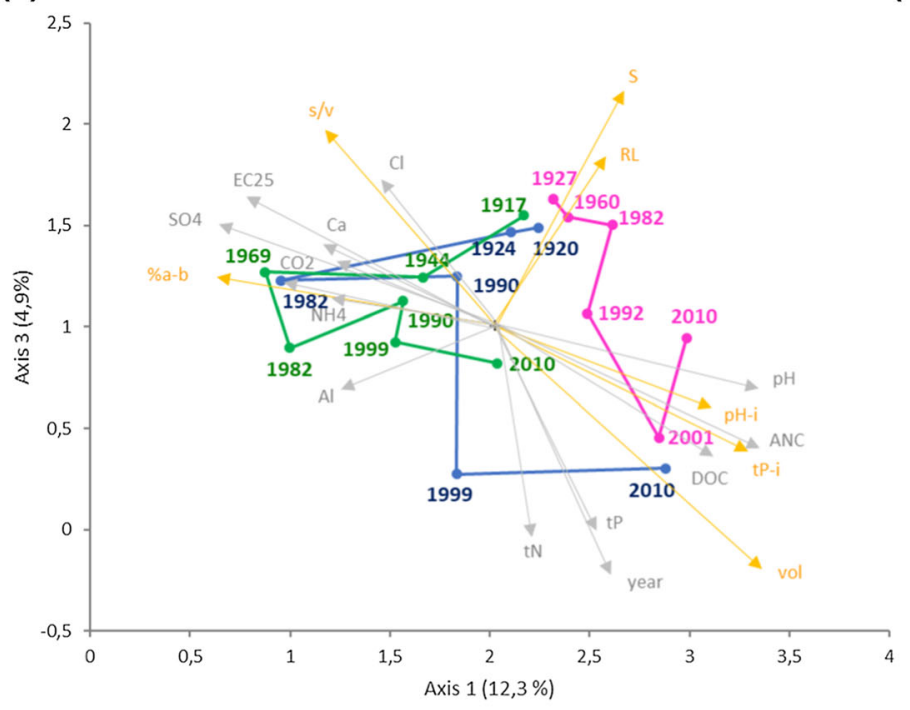

(b)

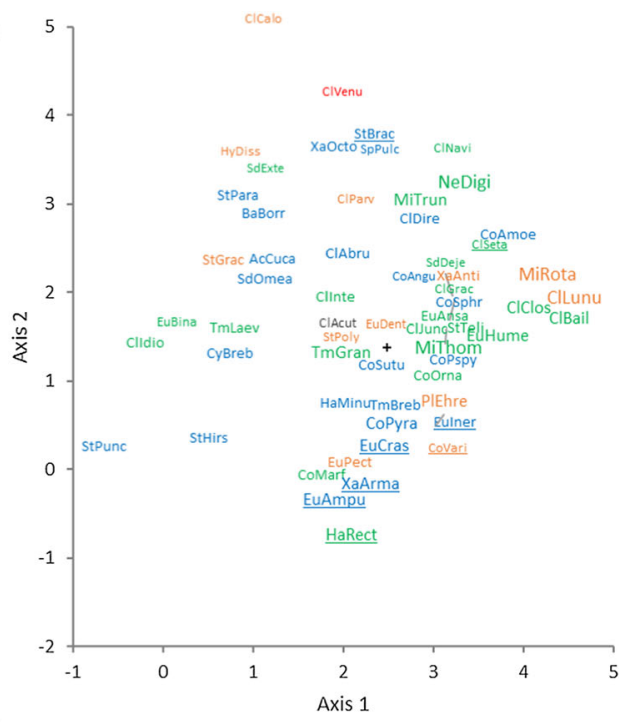

(d)

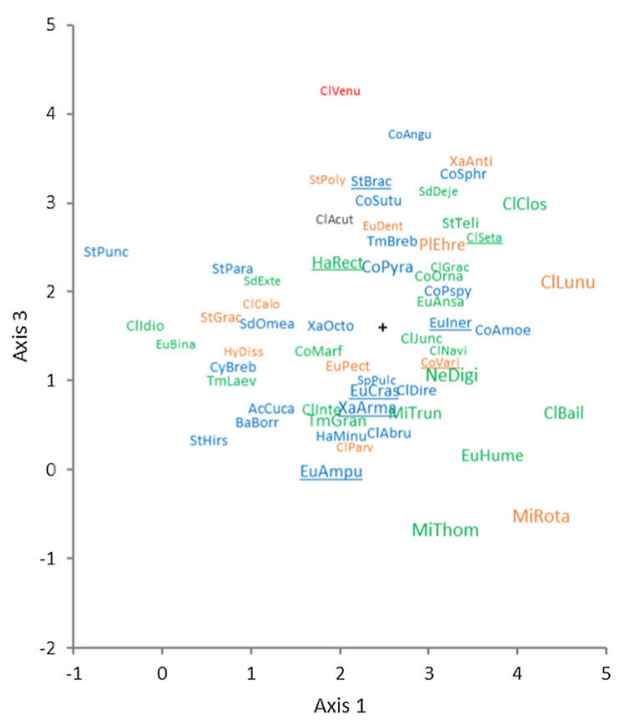

( $r=0.71, p=0.001)$. Stability is strongly negatively correlated with cell content $(r=-0.74, \mathrm{p}<0.001)$ and positively again with the $\mathrm{s} / \mathrm{v}$ ratio $(r=0.51$, $\mathrm{p}<0.05)$. The negative correlation of the total phosphate concentration with the $\mathrm{s} / \mathrm{v}$ ratio $(r=-$ $0.70, p=0.05)$ is striking. That with the cell volume $(r=0.64)$ is nearly significant.

\section{Ordination}

The average scores of the samples per period and the scores of the 60 most common species are shown with their abbreviated names in Fig. 6. Figure 7 gives a three-dimensional impression of the changes in sample scores over time. The correlations of the first three axes with some environmental variables and desmids traits are shown in Table 5 (the fourth axis has no significant correlations with the measured environmental variables).

The first axis of the ordination explains $12.3 \%$ of the total variation in species composition. The first two axes together explain only $17.8 \%$ of the variation. The third and fourth axes add another 7 and $3.2 \%$, respectively. Thus, although this is a pretty good 


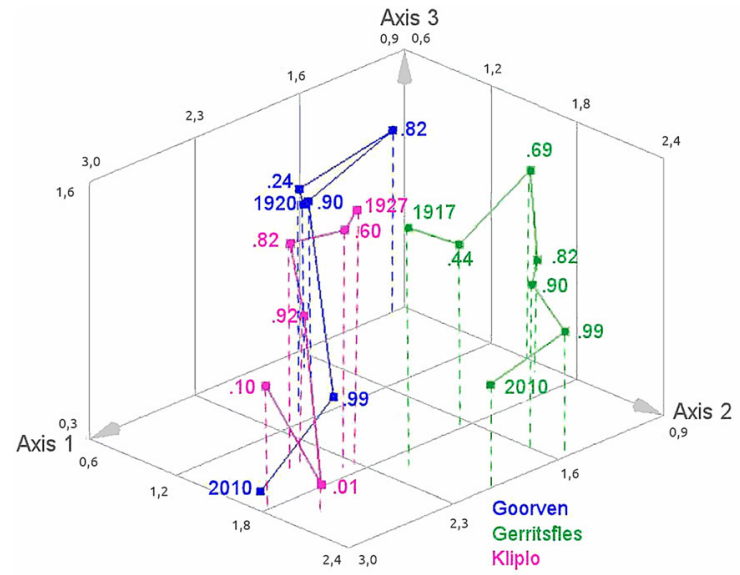

Fig. 7 Development of the mean scores of the samples per period on the first three ordination axes. The periods are indicated with their average year

result, as compared to many other similar ordinations, care should be taken with the interpretation of the results.

In Fig. 6a, the main direction is from bottom left to top right. On the lower left are high concentrations of sulphate and the toxic aluminium that often dissolves at low $\mathrm{pH}$ values in this 'acidification corner' of the diagram. The highest concentrations of carbon dioxide have also been measured here. Perpendicular to the main direction is a gradient of dissolved organic carbon (humic compounds). The concentrations are lowest in the Gerritsfles and highest in the oldest and most recent samples from the Goorven. In this figure, the three moorland pools are well separated from each other. In Gerritsfles and Goorven, the scores decreased from the beginning of the last century until the 1980s (acidification) and increased again. After that, the movement is back again (deacidification). Note also that the drought of 1921 has hardly any influence on the desmids of the last moorland pool, in contrast to those of 1976. In Kliplo, from 1927 until the period of 1992, there is little change on the first two axes; thereafter, the score increases mainly on the first axis.

The samples from Goorven from the late 1990s seem to be almost back to normal, according to Fig. 6a, but the scores of the most recent samples from this pool are much lower on the third axis than they were a century earlier (Figs. 6c, 7). This is also the case for Gerritsfles and Kliplo. The correlations with the environmental variables suggest that these changes
Table 5 Pearson correlation coefficients of selected chemical variables (black) and desmid traits of the first three axes of the ordination

Except $\mathrm{pH}$ and conductivity, chemical variables are logarithmically transformed. $\mathrm{n}=$ number of observations. Highly significant correlations $(\mathrm{p} \leq 0.005)$ are underlined. Environmental variables in normal letters, species characteristics in italics

\begin{tabular}{llllrr}
\hline Variable & Abbrev & $n$ & Axis 1 & \multicolumn{1}{c}{ Axis 2 } & Axis 3 \\
\hline Sulphate & $\mathrm{SO} 4$ & 106 & $\underline{-0.69}$ & $\underline{-0.57}$ & 0.25 \\
Conductivity & $\mathrm{EC} 25$ & 106 & $\underline{-0.62}$ & $\underline{-0.68}$ & $\underline{-0.32}$ \\
Calcium & $\mathrm{Ca}$ & 107 & $\underline{-0.43}$ & $\underline{-0.71}$ & 0.20 \\
Aluminium & $\mathrm{Al}$ & 94 & $\underline{-0.42}$ & $\underline{-0.62}$ & -0.12 \\
Ammonium-nitrogen & $\mathrm{NH} 4$ & 106 & $\underline{-0.41}$ & $\underline{-0.52}$ & 0.07 \\
Carbon dioxide & $\mathrm{CO} 2$ & 60 & $\underline{-0.40}$ & $\underline{-0.63}$ & 0.17 \\
Chloride & $\mathrm{Cl}$ & 108 & -0.28 & $\underline{-0.70}$ & $\underline{0.36}$ \\
Total nitrogen & $\mathrm{tN}$ & 38 & 0.13 & $\underline{-0.63}$ & -0.50 \\
Total phosphate & $\mathrm{tP}$ & 64 & 0.25 & -0.09 & $\underline{-0.50}$ \\
Year & $\mathrm{Year}$ & 112 & 0.29 & 0.22 & $\underline{-0.60}$ \\
Dissolved organic carbon & $\mathrm{DOC}$ & 95 & $\underline{0.55}$ & $\underline{-0.37}$ & -0.33 \\
Acid-neutralizing capacity & $\mathrm{ANC}$ & 105 & $\underline{0.66}$ & $\underline{0.55}$ & -0.30 \\
pH & $\mathrm{pH}$ & 111 & $\underline{0.66}$ & 0.21 & -0.15 \\
Cell volume & Vol & 112 & $\underline{0.67}$ & -0.14 & $\underline{-0.60}$ \\
Surface-volume ratio & $s / v$ & 112 & $\underline{-0.43}$ & $\underline{0.40}$ & $\underline{0.48}$ \\
Number of species & $\mathrm{S}$ & 112 & $\underline{0.33}$ & -0.11 & $\underline{0.59}$ \\
Number of Red List species & $R L$ & 112 & 0.28 & $\underline{-0.46}$ & $\underline{0.42}$ \\
\% atmophytic-benthic species & $\% a-b$ & 112 & $\underline{-0.69}$ & $\underline{-0.18}$ & 0.12 \\
Inferred total phosphate & $t P-i$ & 112 & $\underline{0.66}$ & 0.28 & -0.30 \\
Inferred pH & $p H-i$ & 112 & $\underline{0.54}$ & $\underline{0.37}$ & -0.21 \\
\hline
\end{tabular}


are mainly associated with increases in total nitrogen and total phosphate concentrations and to a somewhat lesser extent, with decreases in sulphate and increases in $\mathrm{pH}$ and acid-neutralizing capacity.

In Gerritsfles, the cell volume is comparatively low and the s/v ratio is high (Fig. 6a). There may be a connection with the low humus content in this pool. The correlations of the inferred $\mathrm{pH}$ correspond reasonably well with those of the measured $\mathrm{pH}$ values, but this is not the case with the inferred and measured total phosphate concentrations. The percentage of atmophytic-benthic species is highest in the years following the 1976 drought, with subsequent acidification. The numbers of species and Red List species are lowest in the Gerritsfles. Figure $6 \mathrm{~b}$ shows that there is a shift from small, oligotrophic to large, (oligo-) mesotrophic species for the most important species.

In the samples from a century ago, the numbers of Red List and other species are relatively high (Fig. 6c). The cell volumes are the highest, and the s/v ratios are the lowest in the most recent samples. Figure $6 \mathrm{~d}$ shows that these include the oligo-mesotrophic Micrasterias rotata and the mesotrophic $M$. thomasiana. The champion in the most acidic period is the small Staurastrum punctulatum, which also has a high surface/volume ratio. The inferred and measured $\mathrm{pH}$ values point in the same direction in Fig. 6c.

\section{Discussion}

Changes in the abiotic environment

The three moorland pools have undergone significant changes in the past century. Goorven and Gerritsfles, in particular, have become strongly acidified by atmospheric deposition of sulphur and nitrogen compounds. Sulphur deposition decreased below the critical level, but nitrogen deposition is still considerably above. Acidification has been intensified by drying up of the soil during extremely dry summers, such as 1976, causing mineralization of the reduced sulphur compounds stored in the soil. Subsequently, acidifying substances such as sulphate and ammonium decreased due to leaching and a reduction in deposition.

The mineralization also released a lot of carbon dioxide, which dissolved in the water when the moorland pools filled up again. In the following decades, the content of free carbon dioxide continuously decreased. Especially in Goorven, there is a supply of carbonic acid with groundwater, so that the $\mathrm{CO}_{2}$ content here is higher than in the other two moorland pools. These changes were less pronounced in Kliplo, because only a small part of the bottom here dried up in 1976. Here, there are still many (reduced) sulphur and nitrogen compounds in the oxygen-poor bottom. The iron phosphates are converted into iron sulphides, and the released phosphates stimulate plankton growth, often causing the water to turn green (van Dam \& Mertens, 2014). In such reduced soils, there is always plenty of hydrogen sulphide present, which is toxic to aquatic organisms.

The intensity of sulphur and nitrogen metabolism (and indirectly also that of phosphate) in the moorland pools has increased due to a temperature increase of about two degrees by climate change since the 1980s (van Kleef et al., 2010; van Dam \& Mertens, 2013). This has promoted the instability (increased disturbance) of the environment for desmids, which will decrease their diversity. Increased phosphate concentrations in acid Norwegian soft-water streams have been shown to diminish diversity of non-diatom algae, including desmids (Schneider et al., 2013, 2018).

\section{Reactions of desmids}

The desmids react to the changing conditions in the moorland pools: compare for example, the correspondence between the measured and inferred $\mathrm{pH}$ changes (Figs. 3a, 4f). Traits like the number of species, conservation value and similarity (Fig. 4a-c) show roughly the same pattern for Goorven and Gerritsfles: highest values at the beginning of the twentieth century, minima in the 1980 s and a limited increase after that.

Compared to the extreme drought of 1976, the drought of 1921 had little influence on the desmid composition (Table 4) and traits (Fig. 4), although on average, fewer species were found in the period 1924-1925 than in the period 1919-1922. However, strong acidification with an increase of a species like Staurastrum punctulatum did not occur at that time. The effects of the 1976 drought lasted much longer than the occasional drought in some (non-acidified) Czech moorland pools, where the desmids recovered after only a few months (Neustupa et al., 2011). 
In Kliplo, the number of species remains high until the 1980s, but then suddenly declines. This also applies to the stability of the desmids in this lake. However, the inferred $\mathrm{pH}$ (Fig. 4f) and the inferred phosphate concentration (Table 3 ) remain more or less constant in Kliplo. The decrease in stability in 1986-1994 (Fig. 4d) is accompanied by increased concentrations of ammonium and sulphate (Fig. 3c, d). The toxicity of sulphides, ammonium or nitrite may vary over time, causing the algal composition to change. Usually, the toxic nitrite-nitrogen is hardly detectable $(<0.02 \mathrm{mg} \mathrm{N} / \mathrm{l})$, but a few times, the concentration was much higher, up to $0,22 \mathrm{mg} \mathrm{N} / \mathrm{l}$ in May 1989 (van Dam \& Mertens, 2019).

\section{Surface and volume}

There is an exponential relationship between the growth rate of microscopic algae and their s/v ratio (Nielsen \& Sand-Jensen, 1990; Reynolds, 2006). Especially, small species of algae, such as small Cosmarium species, can multiply rapidly. Small species usually have a high $\mathrm{s} / \mathrm{v}$ ratio, which allows them to absorb nutrients quickly. The larger species, including Micrasterias, which often have a low s/v ratio, divide much more slowly (Moss, 1973).

Rapid growers are opportunists: they take advantage of favourable environmental conditions at a particular time. However, they are less tolerant of conditions that limit production (stress), such as shortages of light, water, nutrients and suboptimal temperature (Grime, 1977). The slow growers are at an advantage during stress: they often have a larger cell volume and a lower s/v ratio. They have more reserves to get through an unfavourable period (Coesel, 1982).

Highly acidic conditions are a stress factor for the development of desmids. Maintaining a neutral $\mathrm{pH}$ in the cytoplasm requires a lot of energy. Therefore, species with a low s/v ratio (and thus a larger cell volume) may be at an advantage at low $\mathrm{pH}$ values (Černá \& Neustupa, 2010; Bestová, 2019). However, others note that purely ombrotrophic, acidified bogs, with low $\mathrm{pH}$ values, actually harbour smaller species (with higher growth rates and higher $\mathrm{s} / \mathrm{v}$ ratios) than the more $\mathrm{pH}$-neutral sites. This would be due to the generally unstable conditions in the poorly buffered bogs (Neustupa et al., 2013).

The increase in cell size since 1978 and the decrease in the s/v ratio in Goorven and Kliplo are therefore a sign of increased stress. Phosphate deficiency is not the cause (see the above mentioned negative correlation with the $\mathrm{s} / \mathrm{v}$ ratio), whilst nitrogen is not a deficiency in these moorland pools either. Then again, the decrease in $\mathrm{CO}_{2}$ may be a cause, but then it is remarkable that the s/v ratio in the Gerritsfles does not decrease, whilst $\mathrm{CO}_{2}$ does (Fig. 3b).

We cannot agree with the conclusion of Neustupa et al. (2011) that morphometric indicators of desmids are more sensitive to environmental changes than species composition data.

Causes of the changes

Desmids need carbon for their growth and most species absorb it in the form of $\mathrm{CO}_{2}$ (the most common form of inorganic carbon below $\mathrm{pH}$ 6). A limited number of species can take up $\mathrm{HCO}_{3}{ }^{-}$(Moss, 1973; Spijkerman et al., 2005). Phytoplankton (including desmids) in nutrient-poor lakes does not occur below $\mathrm{CO}_{2}$ concentrations of $2 \mathrm{mg} / \mathrm{l}$, roughly corresponding to the most recent concentrations in our moorland pools (Fig. 3b). It is not inconceivable that changes in the species composition of the desmids in our moorland pools are caused by decreasing $\mathrm{CO}_{2}$ concentrations. Goodyer (2014) sighs: 'There are currently no studies looking at desmid growth which disentangle whether the cells respond to $\mathrm{pH}, \mathrm{CO}_{2}$ availability or perhaps other related factors'. See also the discussion in Woelkerling \& Gouch (1976).

On the first two ordination axes (Fig. 6a), factors strongly related to acidification such as calcium, aluminium, sulphate, $\mathrm{pH}$, acid-neutralizing capacity, total nitrogen and carbon dioxide have high $(r>|0.60|)$ correlations. Ions also contribute to electrical conductivity, as does chloride. Because these factors are also strongly intercorrelated, it is not easy to tell which are the causal factors. Phosphate, an essential nutrient, only appears on the third axis with $r=-0.50$.

However, the first three axes of the ordination explain only $25 \%$ of the taxonomic variation between the samples. Perhaps, even more important than the chemical variables mentioned is the spatial structure present in the water. Most desmid species live between macrophytes such as Utricularia and Sphagnum, often between filamentous algae, the so-called metaphyton (Brook, 1981; Pals, 2007). At the beginning of the twentieth century, in Goorven, aquatic macrophytes were much more abundant than in the last decades. At 
that time, peat moss grew 'from bank to bank' in the vicinity of our sampling station; nowadays, it still occurs along the edges (Thijsse, 1927; van Dam, 1987). Peat mosses need a lot of carbon dioxide (Patberg et al., 2013), just like the desmids. Undoubtedly, the increased shading caused by afforestation around Goorven has contributed to reduced growth of both the water and bank plants and the desmids (Coesel et al., 1978). Afforestation also leads to increased evaporation and thus reduced addition of $\mathrm{CO}_{2}$-rich groundwater to the lake.

\section{Comparison with literature data}

In the literature, we could not find examples of continuous desmid monitoring over such a long period as considered here: almost a century with occasional observations over the first 60 years and semi-annual observations over the following 36 years. However, there are examples of repeated sampling in the years 1976-2008 of earlier inventories from the period 1906-1954 in various bogs in Switzerland (Werner, 1977), Berlin (Weddigen \& Geißler, 1980), Serbia (Cvijan \& Laušević, 1991), Poland (Wayda, 2004), Lithuania (Koreiviené \& Kasperovičiené, 2017), the Czech Republic (Št'astný, 2009) and, of course, the Oisterwijk moorland pools (Coesel et al., 1978). The authors compared their 'recent' samples with the results from old publications and not with those from the re-examination of old samples, as we have done. In spite of the uncertainties in the taxonomy, the trends are clear in these inventories: drainage (with accompanying internal eutrophication and increase in $\mathrm{pH}$ ), peat removal or flooding caused the number of desmids to decrease to a greater or lesser extent and the rare species to disappear.
Weddigen \& Geißler (1980) list the numbers of species of desmids from 21 areas in northern Germany between 1925 and 1976. The minimum, median and maximum numbers of species were 5, 33 and 146, respectively. The maximum was attained in the gradient-rich Hechtgiebel near Berlin (Donat 1926). Št'astný (2009) found 203-319 taxa in gradient-rich Czech peatlands. Coesel et al. (1978) found a total of 201 species in Goorven and the three 'Centrale Vennen' near Oisterwijk in the period 1916-1975. In comparison, species numbers at our sites are high with at least 21, median 50 and maximum 100 per moorland pool per period and up to 143 in Kliplo over all periods (Table 4).

Strengths and weaknesses of desmids for biological water quality assessment

In addition to desmids, data on aquatic and riparian plants (macrophytes) and diatoms are abundant for the three sites (Table 6). In total, 49 species of macrophytes, 124 species of diatoms and 179 species of desmids were found here from 1912 to 2014. Their larger number of species make the microscopic algae, particularly the desmids, basically more powerful instruments than the macrophytes to assess the natural and water quality of the moorland pools. The advantage of the microscopic plants is also that, unlike macrophytes, they are not introduced by man and therefore have a better signalling function (Verkaar \& Van Wirdum, 1991; van Tooren, 2021).

However, the question is whether the power of desmids can be fully exploited. Although much knowledge about the ecology of desmids has already been made operational (e.g. Coesel, 2001; Coesel \& Meesters, 2007), the desmids are still little used for

Table 6 Number of samples and species from the three pools in the period 1912-2014

\begin{tabular}{|c|c|c|c|c|c|}
\hline & \multicolumn{2}{|c|}{ Number of samples } & \multicolumn{3}{|c|}{ Number of species } \\
\hline & Diatoms & Desmids & Macrophytes & Diatoms & Desmids \\
\hline Goorven & 83 & 72 & 23 & 78 & 131 \\
\hline Gerritsfles & 88 & 75 & 34 & 77 & 103 \\
\hline Kliplo & 86 & 71 & 31 & 75 & 143 \\
\hline Three pools & 257 & 218 & 49 & 124 & 180 \\
\hline
\end{tabular}

Diatom data from van Dam \& Mertens (2019). Macrophyte data from many different sources, as cited in van Dam (1987), van Dam et al. (2017) and van Dam \& Mertens (2019) 
assessing nature and water quality. The lack of specialists needed for microscopic identification will be one of the reasons for this. For diatoms, there is a shift from microscopic to genetic identification. Internationally, there is already a database with diatom barcodes (Rimet et al., 2018) and one is being developed for the Netherlands (DNA Diatom Biosensor). Such a database for desmids will probably not be created soon. Attempts have been made, but as there is no consistent phylogenetic system for desmids, the road to rapid identification with barcoding is still long (Gontcharov \& Melkonian, 2010; Hoef-Emden, 2012), but see Bestová (2019).

For the time being, expansion of the ecological knowledge of desmids will therefore be based on the morphological species concepts, as laid down in the flora of Coesel \& Meesters (2007).

\section{Conclusion}

Between 1916 and 2014, significant changes occurred in the three moorland pools' desmid species composition due to changes in acidifying atmospheric deposition. The changes were greatest in ponds with relatively flat banks exposed to the air in extremely dry summers. After the dry summer of 1921, the changes were still small, but after the dry summer of 1976, the changes were dramatic, because the reduced sulphur and nitrogen compounds stored in the moorland pool bottom bonded with oxygen acidified the water. The conservation value declined sharply, but increased again until the 1990s, partly due to the decrease in acidifying deposition, which reached its maximum around 1980.

The acid atmospheric deposition continued to decline until the first year of the present century. However, this did not result in a further recovery of the desmid flora; in contrast, the conservation value declined again, as did the stability of the desmid assemblages. The exact causes of this blockage cannot be determined. The following can be considered: internal eutrophication (nutrients), presence of toxic substances (such as hydrogen sulphide), a decline of aquatic plants (substrate), shading by afforestation (light), reduced $\mathrm{CO}_{2}$ supply (carbon source) due to a decrease in local seepage.

These factors are interrelated. In particular, the chemical dynamics due to the large stock of sulphur and nitrogen compounds will not favour the development of rare desmids, which are confined to stable environmental conditions.

Acknowledgements Bart van Tooren initiated the project, and the late Adri van Tooren identified and counted the samples taken between 1916 and 2005. Thanks are due to Jos Sinkeldam, Adrienne Mertens, Karel Beljaars, Jan Buijs, Ton van Eijden, Hessel Hoekstra†, Liesbeth van der Kamp, Walter Mommersteeg and Wim Oostveen for taking samples. Hannie Kooyman-van Blokland $\dagger$ (University of Amsterdam) helped retrieve old samples (currently in Naturalis) from Jacob Heimans $\dagger$, Albert van der Werff $\dagger$, Rita Kwakkestein $\dagger$ and Henk Smit $\dagger$. Further use was made of samples from Bert Salomé $†$ (former Limnological Institute) and samples from Piet Leentvaar $\dagger$, Pieter Schroevers $\dagger$ and Nico Nieser from the collection of the former Research Institute for Nature Conservation (now in the Botanical Garden Meise). Marien van Westen and Frans Kouwets made literature available. Chemical data from 1995 onwards were made available by the water authorities Reest en Wieden, Veluwe and De Dommel and their laboratories. Natuurmonumenten and Staatsbosbeheer gave permission for site visits. The Hugo de Vries Fund made open access publication possible. We thank two anonymous reviewers for their constructive comments.

Author contributions HvD designed the study and coordinated fieldwork. JM performed identifications and counts of samples taken from 2005 onwards, validated the data from older samples and calculated conservation values for all samples. HvD did all other calculations and wrote the text.

Funding Fieldwork until 1994 was funded by the former Research Institute for Nature Management (Ministry of Agriculture, Nature Management and Fisheries). Fieldwork from 1994 until 2005 was performed when HvD was at Grontmij I AquaSense, funded by the Beijerinck-Popping Foundation, the TAO Foundation, the Ministry of Housing, Physical Planning and the Environment, the water authorities Reest en Wieden, Veluwe and De Dommel, the Province of Drenthe and HvD. No funding was received for identification and counting of desmids after 2005, processing of the data and writing of this paper.

Data availability All data are included in van Dam et al. (2021) (https://edepot.wur.nl/547812).

Code availability Not applicable.

\section{Declarations}

Conflict of interest The authors declare no conflict of interest.

Open Access This article is licensed under a Creative Commons Attribution 4.0 International License, which permits use, sharing, adaptation, distribution and reproduction in any medium or format, as long as you give appropriate credit to the original author(s) and the source, provide a link to the Creative Commons licence, and indicate if changes were made. The images or other third party material in this article are included in 
the article's Creative Commons licence, unless indicated otherwise in a credit line to the material. If material is not included in the article's Creative Commons licence and your intended use is not permitted by statutory regulation or exceeds the permitted use, you will need to obtain permission directly from the copyright holder. To view a copy of this licence, visit http://creativecommons.org/licenses/by/4.0/.

\section{References}

Arts, G.H.P., H. van Dam, F.G. Wortelboer, P.W.M. van Beers \& J.D.M. Belgers, 2002. De toestand van het Nederlandse ven. Alterra, Wageningen/AquaSense, Amsterdam/RIVM, Bilthoven.

Bestová, H., 2019. Patterns and processes in desmid communities: insights from functional and phylogenetic approaches. Ph.D. thesis. Charles University, Faculty of Science, Prague.

Bestová, H., F. Munoz, P. Svoboda, P. Škaloud \& C. Violle, (2018): Ecological and biogeographical drivers of freshwater green algae biodiversity: from local communities to large-scale species pools of desmids. Oecologia 186: 1017-1030.

Brook, A.J., 1981. The biology of desmids. University of California Press, Berkeley.

CBS, PBL, RIVM \& WUR, 2019. Verzurende depositie, 1990-2017 (indicator 0184, versie 18, 5 juni 2019). www. clo.nl. Centraal Bureau voor de Statistiek, Den Haag; Planbureau voor de Leefomgeving, Den Haag; RIVM Rijksinstituut voor Volksgezondheid en Milieu, Bilthoven; Wageningen University and Research, Wageningen.

Černá, K.\& J. Neustupa, 2010. The pH-related morphological variations of two acidophilic species of Desmidiales (Viridiplantae) isolated from a lowland peat bog, Czech Republic. Aquatic Ecology 44: 409-419.

Coesel, P.F.M., 1982. Structural characteristics and adaptations of desmid communities. Journal of Ecology 70: 163-177.

Coesel, P.F.M., 1982-1997. De desmidiaceeën van Nederland. Wetenschappelijke Mededelingen K.N.N.V. 153, 157, 170, 220.

Coesel, P.F.M., 1998. Sieralgen en natuurwaarden. Wetenschappelijke Mededeling KNNV 224: 1-56.

Coesel, P.F.M., 2001. A method for quantifying conservation value in lentic freshwater habitats using desmids as indicator organisms. Biodiversity and Conservation 10: 177-187.

Coesel, P.F.M. \& J. Meesters, 2007. Desmids of the lowlands: Mesotaeniaceae and Desmidiaceae of the European lowlands. KNNV Publishing, Zeist.

Coesel, P.F.M., R. Kwakkestein \& A. Verschoor, 1978. Oligotrophication and eutrophication tendencies in some Dutch moorland pools, as reflected in their desmid flora. Hydrobiologia 61: 21-31.

Cvijan, M. \& R. Lauševic, 1991. Desmids of Vlasinsko Lake from peat bog to lake. Archiv für Protistenkunde 139: 21-37.

Donat, A., 1926. Zur Kenntnis der Desmidiaceen des norddeutsche Flachlandes, eine soziologisch-geographische Studie. Pflanzenforschung 5: 1-51.
European Commission, 2013. Interpretation manual of European Union Habitats. Nature ENV B.3. European Commission DG Environment, Brussels.

Förster, K., 1982. Conjugatophyceae. Zygnemales und Desmidiales (excl. Zygnemataceae). In: Huber-Pestalozzi, G. (Hrsg.) Das Phytoplankton des Süßwassers 8(1). Schweizerbart'sche Verlagsbuchhandlung, Stuttgart.

Gontcharov, A. \& M. Melkonian, 2010. A study of conflict between molecular phylogeny and taxonomy in the Desmidiaceae (Streptophyta, Viridiplantae): Analyses of 291 rbcL sequences. Protist 162: 253-267.

Goodyer, E., 2014. Quantifying the desmid diversity of Scottish blanket mires. Ph.D. thesis. University of Aberdeen, Aberdeen.

Grime, J.P., 1977. Evidence for the existence of three primary strategies in plants and its relevance to ecological and evolutionary theory. American Naturalist 111: 1169-1194.

Heimans, J., 1925. De desmidiaceeënflora van de Oisterwijkse Vennen. Nederlandsch Kruidkundig Archief 34: 245-262.

Hettelingh, J.-P., M. Posch \& J. Slootweg, 2017. European critical loads: database, biodiversity and ecosystems at risk. National Institute for Public Health and the Environment, Bilthoven.

Hildrew, A., 2018. Freshwater acidification: Natural history, ecology and environmental policy. International Ecology Institute, Oldendorf.

Jensen, K.W. \& E. Snekvik, 1972. Low pH levels wipe out salmon and trout populations in southernmost Norway. Ambio 1: 223-225

Hoef-Emden, K., 2012. Pitfalls of establishing DNA barcoding systems in protists: The Cryptophyceae as a test case. Plos ONE 7(8, e43652). 1-24.

Koreiviené, J. \& J. Kasperovičiené, 2017. Diversity of green algae in Kamanos raised bog (NW Lithuania) with the aspect of long-term changes in desmids. Botanica Lithuanica 23: $130-138$.

Krieger, W., 1937. Die Desmidiaceen Europas. In: Kolkwitz, R. (Hrsg.) Rabenhorst's Kryptogamenflora von Deutschland, Österreich und der Schweiz. 13(I,1). Akademische Verlagsgesellschaft, Leipzig.

Krieger, W. \& J. Gerloff, 1962-1969. Die Gattung Cosmarium. Cramer, Weinheim. 410p.

Lenzenweger, R, 1996-2003. Desmidiaceenflora von Österreich. Bibliotheca Phycologica 101, 102, 104, 111. Cramer, Berlin.

Moss, B., 1973. The influence of environmental factors on the distribution of freshwater algae: an experimental study II. The role of $\mathrm{pH}$ and the carbon dioxide-bicarbonate system. Journal of Ecology 61: 157-177.

Neustupa, J., K. Černá \& J. Št'asny, 2011. The effects of aperiodic desiccation on the diversity of benthic desmid assemblages in a lowland peat bog. Biodiversity and Conservation 20: 1695-1711.

Neustupa, J., J. Veselá \& J. Št' astny, 2013. Differential cell size structure of desmids and diatoms in the phytobenthos of peatlands. Hydrobiologia 709: 159-171.

Nielsen, S.L. \& K. Sand-Jensen, 1990. Allometric scaling of maximal photosynthetic growth rate to surface/volume ratio. Limnology and Oceanography 35: 177-181. 
Pals, A., 2007. Ecology of desmids in Flemish softwater lakes. Proefschrift Katholieke Universiteit Leuven, Faculteit Wetenschappen.

Patberg, W., G.J. Baaijens, A.J.P. Smolders, A.P. Grootjans \&, J.T.M. Elzenga, 2013. The importance of groundwaterderived carbon dioxide in the restoration of small Sphagnum bogs. Preslia 85: 389-403.

Prescott, G.W., C.E.M. Bicudo \& W.C. Vinyard, 1982. A synopsis of North American desmids. Part II. Desmidiaceae: Placodermae Section 4. University of Nebraska Press, Lincoln.

Reuss, J.O., N. Christophersen \& H.M. Seip, 1986. A critique of models for freshwater and soil acidification. Water, Air and Soil Pollution 30: 909-930.

Reynolds, C.S., 2006. Ecology of phytoplankton. Cambridge University Press, New York.

Rimet, F., E. Gusev, M. Kahlert, M. Kelly, M. Kulikovskiy, Y. Maltsev, D. Mann, M. Pfannkuchen, R. Trobajo, V. Vasselon, J. Zimmermann \& A. Bouchez, 2018. Diat.barcode, an open-access barcode library for diatoms. Scientific Reports 9(15116): 1-12.

Roelofs, J.G.M., E. Brouwer \& R. Bobbink, 2002. Restoration of aquatic macrophyte vegetation in acidified and eutrophicated shallow soft water wetlands in The Netherlands. Hydrobiologia 478: 171-180.

Růžička, J., 1977-1981. Die Desmidiaceen Mitteleuropas 1(1,2). Schweizerbart'sche Verlagsbuchhandlung, Stuttgart.

Schneider, S.C., M. Kahlert \& M.G. Kelly, 2013. Interactions between $\mathrm{pH}$ and nutrients on benthic algae in streams and consequences for ecological status assessment and species richness patterns. Science of the Total Environment 444: 73-84.

Schneider, S.C., F. Oulehle, P. Krám \& J. Hruška 2018. Recovery of benthic algal assemblages from acidification: how long does it take, and is there a link to eutrophication? Hydrobiologia 805: 33-47.

Sørensen, T.J., 1948. A method of establishing groups of equal amplitude in plant sociology based on similarity of species content, and its application to analyses of the vegetation on Danish commons. Kongelige Danske Videnskabernes Selskab, Biologiske Skrifter 5(4): 1-34.

Spijkerman, E., S.C. Maberly \& P.F.M. Coesel, 2005. Carbon acquisition mechanisms by planktonic desmids and their link to ecological distribution. Canadian Journal of Botany 83: 850-858.

Št'astný, J. 2009. The desmids of the Swamp Nature Reserve (North Bohemia, Czech Republic) and a small neighboring bog: species composition and ecological condition of both sites. Fottea 9: 135-148.

Teiling, E., 1967. The desmid genus Staurodesmus, a taxonomic study. Arkiv för Botanik 6: 467-626.

ter Braak, C.J.F. \& P. Śmilauer, 2012. CANOCO reference manual and user's guide: software for ordination (version 5.0). Biometris, Wageningen/České Budějovice.

Thijsse, J.P., 1927. In Oisterwijk. De Levende Natuur 32: $69-72$.

van Dam, H., 1987. Monitoring of chemistry, macrophytes, and diatoms in acidifying moorland pools. Research Institute for Nature Management, Leersum. van Dam, H., 1996. Partial recovery of moorland pools from acidification: indications by chemistry and diatoms. Netherlands Journal of Aquatic Ecology 30: 203-218.

van Dam, H. \& R.F.M. Buskens (1993): Ecology and management of moorland pools: balancing acidification and eutrophication. Hydrobiologia 265: 225-263

van Dam, H. \& A. Mertens,, 2013. Partial recovery of shallow acid-sensitive lakes from acidification. Environmental Scientist 22(2): 36-40.

van Dam, H. \& A. Mertens, 2014. Vennen herstellen gedeeltelijk van verzuring: het gevaar van interne eutrofiëring. Landschap 31: 91-100.

van Dam, H. \& A. Mertens, 2019. Monitoring herstel verzuring en klimaatverandering vennen 1978-2018: temperatuur, hydrologie, chemie, kiezelwieren. Herman van Dam, Adviseur Water en Natuur, Amsterdam.

van Dam, H., C.J. Meesters \& A.J. van Tooren, 2021. Herstellen sieralgen zich van verzuring? Een eeuw monitoring in drie vennen. Herman van Dam, Adviseur Water en Natuur, Amsterdam.

van Dam, H., D. Tempelman, E. Brouwer, K. Hanhart, F.J. van Erve, B.F. van Tooren \& A. Mertens, 2017. Een eeuw monitoring van vennen in Midden-Brabant: basis voor adequaat beheer. Herman van Dam, Adviseur Water en Natuur, Amsterdam/Stichting Semblis, Amsterdam/Onderzoekcentrum B-WARE, Nijmegen/Eelerwoude, Goor/ Van Erve Natuuronderzoek, Haaren/Sieralgenwerkgroep Nederland, Bilthoven/Diatomella, Overasselt.

van Dobben, H.F., J. Mulder, H. van Dam \& H. Houweling, 1992. The impact of atmospheric deposition on the biogeochemistry of moorland pools and surrounding terrestrial environment. Pudoc, Wageningen.

van Dobben, H.F., R. Bobbink, D. Bal \& A. van Hinsberg, 2012. Overzicht van kritische depositiewaarden voor stikstof, toegepast op habitattypen en leefgebieden van Natura 2000. Alterra, Wageningen.

van Kleef, H.H., E. Brouwer, R.S.E.W. Leuven, H. van Dam, A. de Vries-Brock, G. van der Velde \& H. Esselink, 2010. Effects of reduced nitrogen and sulphur deposition on the water chemistry of moorland pools. Environmental Pollution 158: 2679-2685.

van Tooren, B., 2021. Wie kan er tegen grasland zijn dat weer volstaat met margrieten?. De Levende Natuur 122: 8-9.

Verkaar, H.J.P.A. \& G. van Wirdum, 1991. (Her-)introductie: redding of face-lift van de natuur? De Levende Natuur 92: 196-200.

Wayda, M., 2004. Changes in species composition of desmids in the "Błoto" peat bog (the Niepołomice Forest) from 1954 to 2001. Acta Societatis Botanicorum Poloniae 73: 239-246.

Weddigen, U. \& U. Geißler, 1980. Vergleichende Untersuchungen zur Algenflora zweier Berliner Naturschutzgebiete (Pech- und Barssee) unter besonderer Berücksichtigung der Desmidiaceen. Nova Hedwigia 33: 95-144.

Werner, E., 1977. Ein Beitrag zur Kenntnis der Desmidiaceen im Hudelmoos. Mitteilungen der Thurgauischen Naturforschenden Gesellschaft 42: 7-98.

West, W. \& G.S. West, 1905-1912. A monograph of the British Desmidiaceae. 2, 3, 4. Ray Society, London. 
West, W., G.S. West \& N. Carter, 1923. A monograph of the British Desmidiaceae. 5. Ray Society, London.

Woelkerling, W.J. \& S.B. Gough, 1976. Wisconsin desmids. III. Desmid community composition and distribution in relation to lake type and water chemistry. Hydrobiologia 51: $3-32$.
Publisher's Note Springer Nature remains neutral with regard to jurisdictional claims in published maps and institutional affiliations. 